\section{French research also being stifled by autocracy}

Your Editorial 'Scientific glasnost' (Nature 464, 141-142; 2010) highlights parochial anachronisms in the Russian Academy of Sciences that are obstructing the development of a knowledgebased economy. Russia is not alone: science in France has been experiencing similar problems.

Unfortunately for Europe, French politicians do not seem to have properly understood that research is crucial for an efficient economy. Germany is not the only country to demonstrate that research investment of at least $3 \%$ of gross national product (GNP) has positive short-term and medium-term effects on the country's industrial output, thanks to inventions and start-ups less populous nations such as Switzerland and Finland have shown the same.

However, in 2006 France spent only about $2.1 \%$ of GNP on research and development - a proportion more typical of a developing country. Former socialist prime minister Lionel Jospin had planned, before his 2002 defeat, to expand this to more than $3 \%$ of GNP. And in 2007, socialist presidential candidate Segolène Royal vowed to put research at the top of the government's priorities; however, she was not elected. So the decisive victory by a left-wing coalition in France's regional elections last month offers some hope. Even so, the issue of research was notably absent from the pre-election evaluation of regional priorities (Nouvel Observateur 11 March; 2010).

The old French devils of centralism, dirigisme and corporatism in politics and science still prevail. France's main research body, the CNRS, has about 30,000 members and was once an independent agency, relatively successful in basic research. It is now being suffocated by integration into a university system that has shown little competence in managing top-level research. The recently acquired autonomy of local universities is being undermined by plans for their fusion into super-universities.

Also dispiriting is the French government's plan to take responsibility for research investment away from the regions once more - despite the fact that regional investment has just given an essential boost to local public research in places such as Strasbourg, Toulouse, Marseille and Montpellier (see, for example, http://go.nature. com/XDPeN2).

Patience is necessary in Russia, where problems may be explained by the country's recent history. The failure of present-day France to comprehend the issues and implement the policies necessary for economic success is more dangerous and distressing.

Klaus Scherrer Institut Jacques Monod, Bâtiment Buffon, 15 rue Hélène Brion, 75205 Paris Cedex 13, France e-mail: scherrer.klaus@ijm. univ-paris-diderot.fr

\section{Forensics: stronger scientific scrutiny needed in Britain}

I congratulate Nature for highlighting problems that exist in forensic science, and in lowcopy-number DNA profiling in particular (Nature 464, 325 and 347-348; 2010).

Any move intended to improve matters must, in the first instance, be made within the scientific community. As the lord chief justice William Murray told an English court in 1782: "In matters of science, the reasoning of men of science can only be answered by men of science."

The United Kingdom and other jurisdictions must recognize the defects identified by the US
National Academies of Science report 'Strengthening Forensic Science in the United States: A Path Forward' (2009) and others. They must involve the wider scientific community in the validation of forensic techniques, and in scrutinizing the use of those techniques in forensic investigations.

Peter Neufeld and Barry Scheck correctly suggest (Nature 464, $351 ; 2010)$ that, although an accreditation and certification process may be part of the solution to the many underlying problems in forensic practice, this is not a panacea. It is essential for any proposed scheme that the standards applied are based on sound science.

It is time for all jurisdictions to adopt a common approach, using the proposed US model of a truly independent and scientifically sound national institute. This has not so far been achieved neither is it likely to be - by what the National Academies of Science describe as "an extremely complex and decentralized system, with various players, jurisdictions, demands, and limitations". A network of such national institutes would enable the development of robust international standards that could then be tailored to local practice.

The UK response to the documented and public failures in forensic science has been to appoint an independent regulator, Andrew Rennison. The regulator, an ex-policeman funded by the Home Office, chairs an advisory council whose scientific input comes from within the forensic community and from the suppliers of services to the police. The regulator-commissioned review concluded that the low-template DNA techniques were fit for purpose (see http://go.nature. com/3shVJH).

The introspective and isolated position of forensic science within the United Kingdom is further shown by its removal from the Science, Engineering and Manufacturing Sector Skills
Council. Forensic science has been placed, instead, within the Skills for Justice Sector Skills Council, where it is the only 'scientific' component - thereby removing an opportunity for external scientific scrutiny.

I look forward to the development of a satisfactory model in the United Kingdom. In the short term, a fresh, deeper and wider look at the use of low-template DNA techniques, particularly in casework, is overdue.

Allan Jamieson The Forensic Institute, Baltic Chambers, 50 Wellington Street, Glasgow G2 6HJ, UK

e-mail: allanj@theforensicinstitute.com

\section{Forensics: experts disagree on statistics from DNA trawls}

Statistical analysis in DNAfingerprint matching is a case in point of the need for more science in forensics (Nature 464, $325 ; 2010$ )

In 'confirmatory cases', suspects' DNA is found to match that from the crime scene. A serious problem for crime laboratories, however, is how to present the evidentiary value of DNA-profile matches when those matches arise from trawls of the DNA database, sometimes referred to as 'cold hits'. The issue stems from differences in 'frequentist' and Bayesian statistics, and is beyond the ability of most courts to adjudicate.

Statisticians of the frequentist school argue that a trawl involves many independent trials for matching, so that a match from a cold hit within a database of $N$ individuals, each with a match probability $P$, provides a hit with probability NP. Bayesian statisticians, on the other hand, argue that a match between suspect and crime scene provides a likelihood ratio that is independent of whether the match came from a trawl or not - in which case the 